\title{
Antagonistic effects of HTLV-1 Tax oncoprotein on BRCA1 expression and function
}

\author{
Mahmoud Huleihel", Mital Shukron, Azhar Gabarin, Ammar Abukandil, Mordechai Aboud \\ From 16th International Conference on Human Retroviruses: HTLV and Related Viruses \\ Montreal, Canada. 26-30 June 2013
}

HTLV-1 Tax oncoprotein is considered a key factor in HTLV-1 pathogenicity. BRCA1 gene dysfunction can lead to breast cancer development. In contrast to the tumor suppressor nature of BRCA1, Tax is a potent oncoprotein, most of its activities are strictly opposing those of BRCA1. Therefore, we hypothesize that HTLV1 Tax expression in breast epithelial cells can antagonize BRCA1 expression and functionality, thereby sensitizing these cells to malignant transformation by environmental carcinogens. Our objective was to provide molecular and cellular indications to validate this hypothesis. Based on earlier findings that the milk of HTLV-1 infected women is rich in HTLV-1 infected lymphocytes that can transfer the virus into breast epithelial cells, the outcomes of this project may point that HTLV-1 can be a risk factor for the development of breast cancer, with a substantially higher risk to women who practice longterm breastfeeding. Our results showed that Tax strongly inhibited estrogen induced activation of BRCA-1 expression in breast cells by sequestering $\mathrm{CBP} / \mathrm{p} 300$ co-activators. Trying to explore the CBP/p300 associated mechanism of Tax effect on BRCA1 expression, our results suggest that Tax does not prevent the binding of $\mathrm{CBP} / \mathrm{p} 300$ to ER $\alpha$ but rather physically associates with the $\mathrm{ER} \alpha-\mathrm{CBP} / \mathrm{p} 300$ to form a tertiary reporter. Since CBP/p300 complex has several binding domains, we believe that Tax associates with $\mathrm{ER} \alpha-\mathrm{CBP} / \mathrm{p} 300$ complex through binding to $\mathrm{CBP} / \mathrm{p} 300$ rather than to the $E R \alpha$ protein. We have also found that Tax inhibits BRCA1-mediated activation of p53-target promoters. These results support the possibility of HTLV-1 involvement in breast cancer development.

Published: 7 January 2014

\footnotetext{
* Correspondence: mahmoudh@bgu.ac.il

Department of Microbiology, Immunology and Genetics, Faculty of Health Sciences, Ben-Gurion University of the Negev, Beer-Sheva, Israel
}

doi:10.1186/1742-4690-11-S1-P88

Cite this article as: Huleihel et al:: Antagonistic effects of HTLV-1 Tax oncoprotein on BRCA1 expression and function. Retrovirology 2014 11(Suppl 1):P88.
Submit your next manuscript to BioMed Central and take full advantage of:

- Convenient online submission

- Thorough peer review

- No space constraints or color figure charges

- Immediate publication on acceptance

- Inclusion in PubMed, CAS, Scopus and Google Scholar

- Research which is freely available for redistribution

Submit your manuscript at Submit your manuscript at
www.biomedcentral.com/submit
() Biomed Central
C Biomed Central

(c) 2014 Huleihel et al; licensee BioMed Central Ltd. This is an Open Access article distributed under the terms of the Creative Commons Attribution License (http://creativecommons.org/licenses/by/2.0), which permits unrestricted use, distribution, and reproduction in any medium, provided the original work is properly cited. The Creative Commons Public Domain Dedication waiver (http:// creativecommons.org/publicdomain/zero/1.0/) applies to the data made available in this article, unless otherwise stated. 